\title{
Production, active staining and gas chromatography assay analysis of recombinant aminopeptidase P from Lactococcus lactis ssp. lactis DSM 20481
}

\author{
Timo Stressler, Thomas Eisele, Michael Schlayer and Lutz Fischer ${ }^{*}$
}

\begin{abstract}
The aminopeptidase P (PepP, EC 3.4.11.9) gene from Lactococcus lactis ssp. lactis DSM 20481 was cloned, sequenced and expressed recombinantly in E. coli BL21 (DE3) for the first time. PepP is involved in the hydrolysis of proline-rich proteins and, thus, is important for the debittering of protein hydrolysates. For accurate determination of PepP activity, a novel gas chromatographic assay was established. The release of L-leucine during the hydrolysis of L-leucine-L-proline-L-proline (LPP) was examined for determination of PepP activity. Sufficient recombinant PepP production was achieved via bioreactor cultivation at $16{ }^{\circ} \mathrm{C}$, resulting in PepP activity of $90 \mu k_{\text {kat }} \mathrm{L}_{\text {culture. }}^{-1}$. After automated chromatographic purification by His-tag affinity chromatography followed by desalting, PepP activity of $73.8 \mu \mathrm{kat}_{\text {LPP }} \mathrm{L}_{\text {culture }}^{-1}$ was achieved. This was approximately 700 -fold higher compared to the purified native PepP produced by Lactococcus lactis ssp. lactis NCDO 763 as described in literature. The molecular weight of PepP was estimated to be $\sim 40 \mathrm{kDa}$ via native-PAGE together with a newly developed activity staining method and by SDS-PAGE. Furthermore, the kinetic parameters $K_{m}$ and $V_{\text {max }}$ were determined for PepP using three different tripeptide substrates. The purified enzyme showed a pH optimum between 7.0 and 7.5 , was most active between $50^{\circ} \mathrm{C}$ and $60^{\circ} \mathrm{C}$ and exhibited reasonable stability at $0^{\circ} \mathrm{C}, 20^{\circ} \mathrm{C}$ and $37^{\circ} \mathrm{C}$ over 15 days. PepP activity could be increased 6-fold using $8.92 \mathrm{mM} \mathrm{MnCl}_{2}$ and was inhibited by 1,10-phenanthroline and EDTA.
\end{abstract}

Keywords: Lactococcus lactis, Aminopeptidase P, PepP, Gas chromatographic assay, Activity staining, LPP

\section{Introduction}

Aminopeptidase P (PepP; EC 3.4.11.9) is an exopeptidase that removes the $\mathrm{N}$-terminal amino acid at the $\mathrm{P}_{1}$ position [nomenclature following Schechter and Berger (1967)] from a peptide when proline is in the $P_{1}{ }^{\prime}$ position (Cunningham and O'Connor 1997). Several enzymes with the specificity of PepP have been found in species such as Escherichia coli (Yaron and Mlynar 1968; Yoshimoto et al. 1988b), Neisseria gonorrhoeae (Chen and Buchanan 1980), Thermococcus sp. strain NA1 (Lee et al. 2006), Lactococcus lactis ssp. lactis NCDO 763 (Mars and Monnet 1995), Lactococcus lactis ssp. cremoris AM2 (McDonnell et al. 1997) and tissues from

\footnotetext{
* Correspondence: Lutz.Fischer@uni-hohenheim.de

Institute of Food Science and Biotechnology, Department of Biotechnology, University of Hohenheim, Garbenstr. 25, D-70599, Stuttgart, Germany
}

several mammalian species (Hooper et al. 1990; Harbeck and Mentlein 1991). While the physiological role of PepP in bacteria is unclear, mammalian PepP is involved in processes such as the regulation of biologically active peptides, including substance $\mathrm{P}$ and bradykinin (Cunningham and O'Connor 1997; Yaron and Naider 1993).

Due to the unique contribution of proline residues to protein hydrolysate bitterness, much research has focused on the application of proline-specific exopeptidases in hydrolysate debittering strategies due to the general inability of most general aminopeptidases to hydrolyze the imino bond (FitzGerald and O'Cuinn 2006). PepP from lactococcoal strains may contribute to the abolition of bitterness during cheese ripening when peptide degradation is involved during fermentation (McDonnell et al. 1997). Debittering of a tryptic hydrolysate of $\beta$-casein has been described using purified 
general and proline-specific aminopeptidases from Lactococcus lactis ssp. cremoris AM2 (Bouchier et al. 2001). Thus, PepP has industrial potential based on its application to the enzymatic debittering of proline-rich peptide mixtures in foods. In addition to native enzyme production and purification, recombinant DNA technology can be used to express large amounts of interesting enzymes (Oliveira et al. 2011). This possibility greatly expands the range of potential applications for enzymes (e.g., $\beta$-galactosidases) and their economically effective utilization in industrial processes (Oliveira et al. 2011).

PepP activity has previously been determined using different methods, such as a modified colorimetric ninhydrin method (Doi et al. 1981), various spectrophotometric assays employing other peptidases as auxiliary enzymes (proline iminopeptidase; EC 3.4.11.5 or dipeptidyl peptidase IV; EC 3.4.14.5) and substrates such as Gly-Pro- $p$ NA or Gly-Pro-Pro- $p$ NA (Yoshimoto et al. 1988b; Lasch et al. 1988). Furthermore, fluorescencebased assays have been employed to determine PepP activity using different synthesized fluorogenic substrates (Fleminger et al. 1982; Holtzman et al. 1987; Hawthorne et al. 1997; Stöckel-Maschek et al. 2003). However, all of these assays have different disadvantages (Yoshimoto et al. 1988b; Doi et al. 1981) with respect to accurately determining PepP activity.

In this study, we cloned and sequenced the genes encoding PepP from Lactococcus lactis ssp. lactis DSM 20481 and Lactobacillus plantarum NC8. Furthermore, we expressed lactococcal PepP for the first time in E. coli, and following automated purification, we characterized lactococcal PepP and developed a new gas chromatographic assay for accurate PepP enzyme activity determination and a novel specific activity staining method for PepP for use in native-PAGE analysis.

\section{Materials and methods Materials}

All chemicals were obtained from Sigma-Aldrich Chemie GmbH (Schnelldorf, Germany), Roth (Karlsruhe, Germany), AppliChem GmbH (Darmstadt, Germany) or Merck AG (Darmstadt, Germany) and were of analytical-grade purity. Oligonucleotides were obtained via biomers.net $\mathrm{GmbH}$ (Ulm, Germany). Kits and enzymes for the molecular biological work were obtained from Qiagen (Hilden, Germany), Fermentas GmbH (St. Leon-Rot, Germany), New England Biolabs GmbH (Frankfurt am Main, Germany) or Roche (Mannheim, Germany). Standard peptides were obtained from Bachem AG (Bubendorf, Switzerland). Nucleotide sequence analyses were carried out by SRD - Scientific Research and Development GmbH (Bad Homburg, Germany). Chromatography materials (BioFox $40 \mathrm{IDA}_{\text {low }}$ ) for protein purification as well as the Bioline chromatography system were provided by Wissenschaftliche Gerätebau Dr. Ing. Herbert Knauer GmbH (Berlin, Germany). Bioreactor cultivation was performed using the Multifors system (Infors AG, Bottmingen/Basel, Switzerland). For polyacrylamide gel electrophoresis, the MINI-PROTEAN system (Bio-Rad Laboratories $\mathrm{GmbH}$, München, Germany) was employed.

\section{Bacterial strains and culture conditions}

The Lactococcus lactis ssp. lactis DSM 20481 strain was cultivated in Medium 53 [glucose $\left(5 \mathrm{~g} \mathrm{~L}^{-1}\right)$, casein peptone, tryptic digest $\left(10 \mathrm{~g} \mathrm{~L}^{-1}\right)$, yeast extract $\left(5 \mathrm{~g} \mathrm{~L}^{-1}\right)$ and $\left.\mathrm{NaCl}\left(5 \mathrm{~g} \mathrm{~L}^{-1}\right)\right]$ under shaking at $30^{\circ} \mathrm{C}$. The Lactobacillus plantarum NC8 strain was cultivated in de Man, Rogosa and Sharpe (MRS) medium [glucose $\left(20 \mathrm{~g} \mathrm{~L}^{-1}\right)$, casein peptone, tryptic digest $\left(10 \mathrm{~g} \mathrm{~L}^{-1}\right)$, meat extract $\left(10 \mathrm{~g} \mathrm{~L}^{-1}\right)$, yeast extract $\left(5 \mathrm{gL}^{-1}\right)$, Na-acetate $\left(5 \mathrm{gL}^{-1}\right)$, dipotassium hydrogen phosphate $\left(2 \mathrm{~g} \mathrm{~L}^{-1}\right)$, diammonium hydrogen citrate $\left(2 \mathrm{~g} \mathrm{~L}^{-1}\right)$, Tween $80\left(1 \mathrm{~g} \mathrm{~L}^{-1}\right)$, magnesium sulfate heptahydrate $\left(0.2 \mathrm{~g} \mathrm{~L}^{-1}\right)$ and manganese sulfate monohydrate $\left.\left(0.05 \mathrm{~g} \mathrm{~L}^{-1}\right)\right]$ under shaking at $37^{\circ} \mathrm{C}$.

E. coli $\mathrm{DH} 5 \alpha$ (Invitrogen, Carlsbad, USA) and E. coli BL21 (DE3) (Novagen, Madison, USA) were used as the hosts for cloned PCR products and T7 expression work, respectively. Standard protocols were employed for the preparation and transformation of competent $E$. coli cells with plasmid DNA via heat shock (Sambrook and Russell 2001). Cells were cultivated in Luria Bertani (LB) medium [yeast extract $\left(5 \mathrm{~g} \mathrm{~L}^{-1}\right)$, peptone $\left(10 \mathrm{~g} \mathrm{~L}^{-1}\right)$ and $\left.\mathrm{NaCl}\left(5 \mathrm{~g} \mathrm{~L}^{-1}\right)\right]$ supplemented with the appropriate antibiotic [ampicillin $\left(100 \mu \mathrm{g} \mathrm{mL} \mathrm{m}^{-1}\right)$ ] and agar $\left(15 \mathrm{~g} \mathrm{~L}^{-1}\right)$ for agar plates. Unless otherwise stated, all cultures were grown under shaking at $37^{\circ} \mathrm{C}$.

\section{Cloning, construction of expression vectors and sequencing of pepP}

Total genomic DNA from either Lactococcus lactis or Lactobacillus plantarum was extracted using the phenol/chloroform method. Briefly, $5 \mathrm{~mL}$ of an overnight culture was centrifuged (10 $\mathrm{min}, 3,000 \times \mathrm{g}$ ), resuspended in suspension buffer $(400 \mu \mathrm{L} ; 25 \mathrm{mM}$ Tris/ $\mathrm{HCl}, 50 \mathrm{mM}$ glucose and $10 \mathrm{mM}$ EDTA, $\mathrm{pH}$ 8.0) containing lysozyme $\left(1 \mathrm{ng} \mathrm{mL} \mathrm{m}^{-1}\right)$ and mutanolysin $\left(50 \mathrm{U} \mathrm{mL}^{-1}\right)$ and incubated for $45 \mathrm{~min}$ at $37^{\circ} \mathrm{C}$. After the addition of $10 \%(\mathrm{w} / \mathrm{v}) \mathrm{SDS}$ $(40 \mu \mathrm{L})$, a further incubation $\left(15 \mathrm{~min}, 65^{\circ} \mathrm{C}\right)$ was carried out. A second centrifugation step (10 $\mathrm{min}, 17,000 \times \mathrm{g}$ ) was performed after the addition of phenol/chloroform $(500 \mu \mathrm{L})$. The supernatant was gently mixed with $3 \mathrm{M}$ Na-acetate $[10 \%(\mathrm{v} / \mathrm{v})]$, ice-cold isopropanol [100\% (v/v)] and centrifuged (5 min, 17,000 x $g$ ) for DNA precipitation. The DNA was washed with ethanol [500 $\mu \mathrm{L}, 70 \%$ $(\mathrm{v} / \mathrm{v})]$ and resuspended in elution buffer $(50 \mu \mathrm{L}$, Qiagen $)$ containing RNase $\left(20 \mu \mathrm{g} \mathrm{mL}^{-1}\right)$. 
For the amplification of the pepP gene of Lactococcus lactis ssp. lactis DSM 20481 (pepP-Lc), the primers NdeI_pepP-Lc_for (5'-AGGAGAATAAACATATGAGA ATTGAAAAATTAAAAG-3') and XhoI_pepP-Lc_rev (5'-ACTAATCTCGAGAATAACGATAAGCTCTTTTG$\left.3^{\prime}\right)$, were employed based on the nucleotide sequence of pepP from Lactococcus lactis subsp. lactis IL1403 (EMBL: AAK04789) available in the UniProt data base (UniProt ID: Q9CHN7). For the pepP gene of Lactobacillus plantarum NC8 (pepP-Lb), the primers NdeI_pepP-Lb_for (5'GTGACGAACATATGAGTCGAGTTGAACGGTTAC-3') and XhoI_pepP-Lb_rev (5'-ACTAATCTCGAGTAAAATC AGTAAATCACGAGTTGC-3') based on the nucleotide sequence of the pepP gene from Lactobacillus plantarum WCFS1 (EMBL: CCC78909) available in the UniProt data base (UniProt ID: F9UNX0) were used in combination with HotStar HiFidelity polymerase (Qiagen) according to the instructions of the manufacturer. Amplification of the pepP genes was carried out as follows: a preliminary denaturation was performed at $95^{\circ} \mathrm{C}$ for $5 \mathrm{~min}$, followed by 12 cycles of denaturation $\left(15 \mathrm{~s}\right.$ at $\left.95^{\circ} \mathrm{C}\right)$, annealing (1 min at $52^{\circ} \mathrm{C}$ for pepP-Lc or at $60^{\circ} \mathrm{C}$ for pepP-Lb; both reduced by $1^{\circ} \mathrm{C}$ per cycle) and extension ( 2 min at $72^{\circ} \mathrm{C}$ ), with a subsequent 35 cycles of denaturation $(15 \mathrm{~s}$ at $\left.95^{\circ} \mathrm{C}\right)$, annealing $\left(1 \mathrm{~min}\right.$ at $50^{\circ} \mathrm{C}$ for pepP-Lc or $55^{\circ} \mathrm{C}$ for pepP-Lb) and extension $\left(2 \mathrm{~min}\right.$ at $\left.72^{\circ} \mathrm{C}\right)$, and a final extension was then performed at $72^{\circ} \mathrm{C}$ for $10 \mathrm{~min}$.

The amplified pepP gene PCR products were purified (QIAquick Gel Extraction Kit) after electrophoresis in an agarose gel $[1 \%(\mathrm{w} / \mathrm{v})]$. The purified PCR products and the expression vector [pET20b $(+)]$ were digested with the NdeI and XhoI restriction enzymes and purified as described above. Ligations were performed according to manufacturer's (Promega) protocols using T4-ligase (Roche). For nucleotide sequence analysis (SRD), a plasmid mini-preparation (Fermentas) was carried out after overnight culture of $E$. coli DH5 $\alpha$ transformed with the constructed expression vector pET20b $(+)$ pepP-Lc or pET20b (+)_pepP-Lb. Database searches were performed online with the programs blastn and blastp provided by the BLAST server (Altschul et al. 1990; Gish and States 1993). Blastp was used to align the amino acid sequences. All parameters were set at their default values.

\section{Expression of recombinant PepP in E. coli BL21 (DE3)}

Transformed E. coli BL21 (DE3) strains were grown in 2xYT medium [yeast extract $\left(10 \mathrm{~g} \mathrm{~L}^{-1}\right)$, tryptone $\left(16 \mathrm{~g} \mathrm{~L}^{-1}\right)$ and $\left.\mathrm{NaCl}\left(10 \mathrm{~g} \mathrm{~L}^{-1}\right)\right]$ containing glucose $\left.\left(15 \mathrm{~g} \mathrm{~L}^{-1}\right)\right]$ supplemented with ampicillin $\left(100 \mu \mathrm{g} \mathrm{mL} \mathrm{m}^{-1}\right)$. Precultures were incubated at $20^{\circ} \mathrm{C}$ on a rotary shaker. The first precultures were cultivated for $24 \mathrm{~h}$ and the second for $19 \mathrm{~h}$. The main cultures $(800 \mathrm{~mL})$ were performed in a bioreactor parallel system (Multifors) and inoculated with $10 \%(\mathrm{v} / \mathrm{v})$ preculture, each. The $\mathrm{pH}$ (6.5) was regulated using $3 \mathrm{M} \mathrm{NaOH}$ and $1 \mathrm{M} \mathrm{H}_{3} \mathrm{PO}_{4}$. The cultures were gas flushed $(1 \mathrm{vvm})$ with air, and the $\mathrm{pO}_{2}$ was maintained over $30 \%$ by stirring at $500 \mathrm{rpm}$. The temperature was held constant at $16^{\circ} \mathrm{C}$, and the optical density $\left(\mathrm{OD}_{600 \mathrm{~nm}}\right)$ was determined with a spectral photometer at $600 \mathrm{~nm}$. As the $\mathrm{OD}_{600}$ reached 5, the cells were induced by addition of $0.5 \mathrm{mM}$ IPTG. The cultures were stopped after $60 \mathrm{~h}$ of cultivation. Glucose concentrations were analyzed using a photometric assay at $340 \mathrm{~nm}$ with the HK/G6P-DH-system (Megazyme International Ireland, Co. Wicklow, Ireland) in microtiter plates, based on the manufacturer's protocol for the D-glucose/D-fructose test kit (R-Biopharm AG, Darmstadt, Germany; product code 10139106 035). For determination of cell dry weights (cdw), samples $(1 \mathrm{~mL})$ were first centrifuged $\left(8,000 \times \mathrm{g}, 5 \mathrm{~min}, 4^{\circ} \mathrm{C}\right)$, and the cell pellets were resuspended in saline $(1 \mathrm{~mL})$ and centrifuged again. The obtained cell pellets were dried using a rotation vacuum concentrator (RVC 2-33 IR, Martin Christ Gefriertrocknungsanlagen $\mathrm{GmbH}$, Osterode am Harz, Germany) for $6 \mathrm{~h}$ to $8 \mathrm{~h}\left(10 \mathrm{mbar}, 40^{\circ} \mathrm{C}\right)$ until the weight was constant. For expression analyzes during cultivations $10 \mathrm{~mL}$ cell suspensions were centrifuged $\left(8,000 \times \mathrm{g}, 5 \mathrm{~min}, 4^{\circ} \mathrm{C}\right)$, and the pellets were washed with saline and stored at $-20^{\circ} \mathrm{C}$. Crude cell extracts were prepared following suspension in $50 \mathrm{mM}$ Tris/ $\mathrm{HCl}$ buffer $(\mathrm{pH} 7.0)$ by sonification and centrifugation $\left(8,000 \times g, 5 \mathrm{~min}, 4^{\circ} \mathrm{C}\right)$. After culturing, the cells were harvested by centrifugation $\left(8,000 \times \mathrm{g}, 15 \mathrm{~min}, 4^{\circ} \mathrm{C}\right)$, washed with saline and stored at $-20^{\circ} \mathrm{C}$.

\section{Automated purification of PepP}

For protein purification, $15 \%(\mathrm{w} / \mathrm{v})$ cell suspensions in $50 \mathrm{mM}$ Tris/ $\mathrm{HCl}$ buffer ( $\mathrm{pH} 8.0$ ) containing $500 \mathrm{mM}$ $\mathrm{NaCl}$ were prepared and disrupted by sonification. The crude extracts were centrifuged $\left(8,000 \times \mathrm{g}, 5 \mathrm{~min}, 4^{\circ} \mathrm{C}\right)$, and the resultant supernatants were passed through $0.45 \mu \mathrm{m}$ filters. Purification and desalting were performed using an automated Bioline system (Knauer). The system was equipped with a pump (S 1000), DAD (S 2850), conductivity meter (S 2900) and a 6-port/3-channel manual injection valve. Chromatography columns were connected to the system via two 7-port/1-channel switching valves (see Additional file 1). Peak parking was accomplished with two 6-port/3-channel switching valves (see Additional file 1). Eluted proteins were collected with a fraction collector (Frac 3050). The fraction collector was cooled using a thermostat (Ministat 230, Huber, Germany) at $4^{\circ} \mathrm{C}$. The Bioline chromatography system was controlled by the ChromGate Data System V.3.3.2.

The filtered cellular extract was applied to BioFox 40 $\mathrm{IDA}_{\text {low }}$ (Knauer) resin charged with $\mathrm{Ni}^{2+}[1$ column volume $(\mathrm{CV})=11 \mathrm{~mL}$. The sample was loaded onto a 
column with a flow rate of $1 \mathrm{~mL} \mathrm{~min}{ }^{-1}$, and the column was washed at a flow rate of $2 \mathrm{~mL} \mathrm{~min}^{-1}$ with $4 \mathrm{CV}$ of $50 \mathrm{mM}$ Tris/HCl buffer $(\mathrm{pH} 8.0)$ containing $500 \mathrm{mM}$ $\mathrm{NaCl}$ and $10 \mathrm{mM}$ imidazole to avoid nonspecific binding. PepP was eluted in a step in which the imidazole concentration was increased to $500 \mathrm{mM}$. The eluted protein fractions exhibiting PepP activity were injected into a Superloop $^{\mathrm{TM}}$ (GE Healthcare) from 39.75 - $46 \mathrm{~min}$ and desalted (50 mM Tris/HCl buffer, $\mathrm{pH}$ 7.0) automatically using HiPrep $^{\text {TM }}$ 26/10 desalting columns (GE Healthcare). Desalted protein fractions showing PepP activity were collected in $5 \mathrm{~mL}$ volumes. The purified enzyme was finally stored at $-80^{\circ} \mathrm{C}$.

\section{Polyacrylamide gel electrophoresis (PAGE)}

After cell disruption (sonification), samples were divided into soluble and insoluble fractions. These samples as well as the purified PepP [5 $\mu$ g of protein each (Bradford 1976)] were analyzed via sodium dodecyl sulfate (SDS)PAGE [12.5\%; (Laemmli 1970)]. A standard molecular weight protein mixture was used as reference (NEB). Gels were stained for protein detection with Coomassie Brilliant Blue.

Native-PAGE (8\%) was carried out on ice with the soluble samples before and after purification [unless otherwise stated, $5 \mu \mathrm{g}$ protein was added per lane; (Bradford 1976)]. A native standard molecular weight protein mixture obtained from SERVA Electrophoresis $\mathrm{GmbH}$ (Heidelberg, Germany) was used as reference. The gels were stained for protein detection with Coomassie Brilliant Blue.

To detect the specific activity of PepP, the staining method of Lewis and Harris (1967) was used, with some modifications. The native-PAGE gel was washed two times with $50 \mathrm{~mL}$ of Tris/ $\mathrm{HCl}$ buffer $(\mathrm{pH} 7.0)$ containing $2 \mathrm{mM} \mathrm{MnCl}_{2}$. Then, $10 \mathrm{~mL}$ of solution A [50 mM Tris/ $\mathrm{HCl}$ buffer ( $\mathrm{pH}$ 7.0) containing $2 \mathrm{mM} \mathrm{MnCl}_{2}, 2 \mathrm{mg}$ $o$-dianisidine dihydrochloride, $5 \mathrm{mg}$ LPP, $1 \mathrm{U}$ L-amino acid oxidase (LAOX) and $240 \mathrm{U}$ peroxidase (PER)] was mixed with $10 \mathrm{~mL}$ of solution $\mathrm{B}$ [50 $\mathrm{mM}$ Tris/ $\mathrm{HCl}$ buffer (pH 7.0) containing $2 \mathrm{mM} \mathrm{MnCl} 2$ and $2 \%(\mathrm{w} / \mathrm{v}$ ) agarose; temperature $55^{\circ} \mathrm{C}-60^{\circ} \mathrm{C}$, thus producing solution $\mathrm{C}$. The washed native-PAGE gel was covered with solution $\mathrm{C}$ and incubated at $37^{\circ} \mathrm{C}$ until an orange/brown-colored band appeared (see Additional file 2 for visualization scheme).

The activity staining was also used to verify the separation process of the recombinant PepP from the native PepP from E. coli. For these experiments, the host E. coli BL21 (DE)_pET20b (+) without the pepP gene (control) was purified using the same method as was employed for E. coli BL21 (DE)_pET20b (+)_pepP-Lc. In the control, PepP activity was only detected at $200 \mathrm{kDa}$ in the crude cell extract as well as in the flow-through from the $\mathrm{Ni}^{2+}$ affinity column. The protein concentration loaded on the native-PAGE gel in this case was 10-fold higher compared to the recombinant PepP due to the low PepP activity in the control. Furthermore, it was approximately 5 -fold longer before active bands appeared, and only weak bands at approximately $200 \mathrm{kDa}$ could be detected (data not shown).

\section{Measurement of PepP activity using a gas chromatographic assay}

The peptide L-Leu-L-Pro-L-Pro (LPP) was usually used as a substrate to determine PepP activity following standard procedures. The standard assay was carried out as follows: $5 \mu \mathrm{L}$ of internal standard (ISTD; $5 \mathrm{mg} \mathrm{mL}^{-1}$ phenylalanine in $\left.\mathrm{H}_{2} \mathrm{O}_{\mathrm{dd}}\right)$ and $5 \mu \mathrm{L}$ of $\mathrm{MnCl}_{2}(150 \mathrm{mM}$ in $\mathrm{H}_{2} \mathrm{O}_{\text {dd }}$ ) were added to $50 \mu \mathrm{L}$ of enzyme solution (diluted in $50 \mathrm{mM}$ Tris/HCl buffer, $\mathrm{pH}$ 7.0). After preincubation $\left(5 \mathrm{~min}\right.$ at $\left.40^{\circ} \mathrm{C}\right), 10 \mu \mathrm{L}$ of LPP solution $\left(10 \mathrm{mg} \mathrm{mL}^{-1}\right.$, dissolved in $\mathrm{H}_{2} \mathrm{O}_{\mathrm{dd}}$ ) was added to the reaction mixture. The reaction was stopped after 5 to $10 \mathrm{~min}$ by addition of $5 \mu \mathrm{L}$ of $1 \mathrm{M} \mathrm{HCl}$. After centrifugation $(8,000 \times g$, $5 \mathrm{~min}$ ), $60 \mu \mathrm{L}$ of the solution was transferred to a glass vial, and the amino acids and di- and tripeptides (substrates and products) were derivatized as described in the literature (Husek 1991), with some modifications. The sample was mixed with $80 \mu \mathrm{L}$ of ethanol/pyridine (ratio 4:1) solution, and $10 \mu \mathrm{L}$ of ethyl chloroformate (ECF) was added. Next, the solution was shaken $(1,000 \mathrm{rpm})$ at room temperature for $5 \mathrm{~min}$, and $100 \mu \mathrm{L}$ of chloroform (containing 1\% ECF) was then added, followed by shaking again for $5 \mathrm{~min}$ at $1,000 \mathrm{rpm}$. For phase separation, the reaction mixture was allowed to stand at room temperature without shaking for $5 \mathrm{~min}$. Following this, $60 \mu \mathrm{L}$ of the chloroform phase (the lower phase) was transferred to the $\mathrm{GC}$ vial and injected.

A Focus (Thermo Scientific, Germany) gas chromatography system equipped with an AS3000 auto sampler, flame ionization detector and TR-5 column (7 $\mathrm{m} \mathrm{x}$ $0.32 \mathrm{~mm} \times 0.25 \mu \mathrm{m}$; Thermo Scientific) was used for analysis of amino acids and di- and tripeptides. The initial column temperature was set to $80^{\circ} \mathrm{C}$ for $30 \mathrm{sec}$ and then increased to $320^{\circ} \mathrm{C}$ at $35^{\circ} \mathrm{C} \mathrm{min}-1$ and held at $320^{\circ} \mathrm{C}$ for $5 \mathrm{~min}$. The detector and injector were thermostated at $375^{\circ} \mathrm{C}$ and $290^{\circ} \mathrm{C}$, respectively. Helium was used as the carrier gas at a flow rate of $3 \mathrm{~mL} \mathrm{~min}{ }^{-1}$. The injection volume was $1 \mu \mathrm{L}$ using splitless mode. One katal of PepP activity was defined as the amount of enzyme that released $1 \mathrm{~mol}$ of L-leucine (or another amino acid, depending on the substrate) per second. The specific activity was defined as the proteolytic activity per $\mathrm{mg}$ of protein used in this assay. The protein concentration was quantified using bovine serum albumin as a standard (Bradford 1976). 


\section{Characterization of PepP}

Characterization was carried out using purified PepP (see above).

\section{Determination of enzyme kinetics}

The kinetic parameters $\left(K_{m}\right.$ and $V_{\text {max }}$ ) of PepP were determined with the substrates L-Leu-L-Pro-L-Pro (LPP), L-Ile-L-Pro-L-Pro (IPP) and L-Val-L-Pro-L-Pro (VPP). Standard conditions for PepP activity determination (see above) were used, except regarding the substrate concentration in assay. The applied substrate concentrations ranged from $0.085 \mathrm{mM}$ to $12.2 \mathrm{mM}$ depending on the substrate.

\section{Effect of $\mathrm{pH}$ and temperature on the enzyme activity}

To determine the $\mathrm{pH}$ profile of PepP, the activity was assayed under standard conditions (see above), except that the enzyme was diluted in the corresponding buffer. The $\mathrm{pH}$ value ranged from 5.0 to 8.5 .

To assess the effect of temperature on enzyme activity, the activity was assayed under standard assay conditions (see above), except that the assay temperature was varied between $20^{\circ} \mathrm{C}$ and $70^{\circ} \mathrm{C}$. To provide temperature stability, the enzyme solution was incubated at different temperatures ranging from $0^{\circ} \mathrm{C}$ to $50^{\circ} \mathrm{C}$ over a period of 15 days. The residual activity was subsequently measured under standard assay conditions (see above).

\section{Effects of freezing and thawing}

To assess the effect of freezing, aliquots of the enzyme solution were frozen at $-80^{\circ} \mathrm{C}$ and analyzed over a period of 15 days using a standard PepP activity assay.

The influence of freeze cycles on the PepP enzyme activity was determined by freezing the enzyme solution at $-80^{\circ} \mathrm{C}$, then defrosting it, analyzing PepP activity, and freezing the solution again. A total of 6 freeze cycles were performed.

\section{Effect of $\mathrm{Mn}^{2+}$ on enzyme activity}

To determine the effect of different $\mathrm{Mn}^{2+}$ concentrations of PepP activity, standard conditions for PepP activity determination (see above) were applied, except that different concentrations of $\mathrm{MnCl}_{2}(0 \mathrm{mM}$ to $14.28 \mathrm{mM}$ in the assay) were tested.

\section{Effects of inhibitors, cations, metal chelators, reducing agents and solvents on enzyme activity}

The tested substances were dissolved or diluted in $\mathrm{H}_{2} \mathrm{O}_{\mathrm{dd}}$, DMSO, acetone or ethanol, depending on the substance. The assay conditions were the same as under the standard protocol (see above). Different from the standard protocol, $7 \mu \mathrm{L}$ of the test substance and $43 \mu \mathrm{L}$ of enzyme solution were used instead of $50 \mu \mathrm{L}$ of enzyme solution, and the preincubation time was from
5 min to $15 \mathrm{~min}$. All metal ions were added as chlorides to prevent any influence of anions.

\section{Results}

Cloning and sequencing of the pepP genes of Lactococcus lactis ssp. lactis DSM 20481 and Lactobacillus plantarum NC8

Amplification of the pepP gene from the genome of Lactococcus lactis ssp. lactis DSM 20481 resulted in an 1100-bp-long PCR product (pepP: 1059 bp). The fragment was cloned into the pET20b (+) expression vector, producing pET20b $(+)$ pepP-Lc. This vector was sequenced (see Additional file 3 for sequence) and used for expression in the E. coli BL21 (DE3). The new nucleotide sequence of Lactococcus lactis ssp. lactis DSM 20481 (accession number: JX155860) was compared (blastn) to other pepP genes, showing 99\% identity to Lactococcus lactis ssp. lactis KF147, Lactococcus lactis ssp. lactis CV56 and Lactococcus lactis ssp. lactis IL1403. The identities shared with the pepP genes of Lactococcus lactis ssp. cremoris NZ9000 and Lactococcus lactis ssp. cremoris MG1363 were 86\%. Alignment of the obtained amino acid sequence (blastp) to other PepP sequences showed 99\% amino acid sequence identity to Lactococcus lactis ssp. lactis IL1403 (1 different amino acid) and 91\% amino acid sequence identity to Lactococcus lactis ssp. cremoris MG1363 (32 different amino acids). The amplification of the pepP gene from the genome of Lactobacillus plantarum NC8, resulted in an $\sim 1100$-bp-long PCR product (pepP: $1062 \mathrm{bp})$, which was then treated as described above, producing pET20b $(+) \_$pepP-Lb (see Additional file 4 for the sequence). The sequenced pepP gene of $L b$. plantarum NC8 (current work) was $100 \%$ identical to the current published sequence of the pepP gene from $L b$. plantarum NC8 (UniProt ID: H3P3J7). Furthermore, the nucleotide sequence was $100 \%$ identical to the putative pepP gene of Lactobacillus plantarum ssp. plantarum ST-III. Additionally, 99\% identity of the newly obtained pepP gene was observed with Lactobacillus plantarum JDM1 and Lactobacillus plantarum WCFS1. Alignment of the amino acid sequence (blastp) to other PepP sequences from Lactobacillus plantarum strains with less than $100 \%$ nucleotide sequence identity showed 100\% amino acid sequence identity for Lactobacillus plantarum JDM1 and 99\% amino acid sequence identity for Lactobacillus plantarum WCFS1 (1 different amino acid).

\section{Recombinant expression of PepP in E. coli}

In preliminary shaking flasks experiments the recombinant expression of PepP from Lactobacillus plantarum NC8 as well as Lactococcus lactis ssp. lactis DSM 20481 was studied. The cultivation temperatures varied between $4^{\circ} \mathrm{C}$ and $37^{\circ} \mathrm{C}$. At higher temperatures $\left(30^{\circ} \mathrm{C}\right.$ and 
$37^{\circ} \mathrm{C}$ ), no active recombinant protein was detected in the soluble fractions after cell disruption, but a strong overexpression band was observed following SDS-PAGE analysis of the insoluble protein fraction (inclusion bodies; data not shown). Cultivation at lower temperatures $\left(4^{\circ} \mathrm{C}\right.$ and $\left.20^{\circ} \mathrm{C}\right)$ resulted in a recombinant protein overexpression band in both the soluble and insoluble protein fractions after cell disruption (data not shown). Similar results were obtained using E. coli C41 (DE3) and E. coli C43 (DE3) as hosts for expression. The expression systems containing partial soluble PepP were tested for enzymatic function using a novel, specific PepP activity assay based on the release of L-leucine from the substrate LPP (Figure 1).

To determine the background activity of the $E$. coli BL21 (DE3) expression host, E. coli BL21 (DE) transformed with pET20b $(+)$ without the pepP gene (reference) was cultivated under the same conditions described above. The background PepP activity of the reference was approximately $1 \%$ of that detected in the E. coli BL21 (DE)_ pET20b (+)_pepP-Lc expression system (data not shown). Regarding the putative PepP from Lactobacillus plantarum NC8, using the expression system E. coli BL21 (DE)_ pET20b (+)_pepP-Lb, no increase of PepP activity compared to the reference was achieved (data not shown). Additionally, we cultivated E. coli BL21 (DE)_pET20b (+)_pepP-Lc in shaking flasks at $37^{\circ} \mathrm{C}$ and cooled the cultures to $4^{\circ} \mathrm{C}$ and $20^{\circ} \mathrm{C}$ prior induction. However, in these cases, no PepP expression was detected in the soluble protein fraction (data not shown). Therefore, all further cultivations were performed using a bioreactor at a constant temperature of $16^{\circ} \mathrm{C}$, and induction (0.5 mM IPTG) was carried out at $\mathrm{OD}_{600 \mathrm{~nm}}=5$ (Figure 2). After $60 \mathrm{~h}$ of cultivation, an intracellular PepP activity of $90 \mu \mathrm{kat}_{\mathrm{LPP}} \mathrm{L}_{\text {culture }}^{-1}$ was achieved (for sample preparation, see Materials and Methods). It can be assumed that even higher activity yields could be possible under longer cultivations times because glucose was not fully consumed during this cultivation.

\section{Automated purification of recombinant PepP and molecular mass estimation}

PepP was purified automatically using a $\mathrm{Ni}^{2+}$ affinity column, with subsequent desalting via two HiPrep ${ }^{\text {TM }}$ 26/10 columns (Figure 3). Therefore, two 7-port/1-channel switching valves were employed for connection of the chromatography columns to the chromatography system. For "peak parking" and automatic injection of the parked proteins, two 6-port/3-channel switching valves were used (see Additional file 1). PepP was first purified using a $\mathrm{Ni}^{2+}$ affinity column operated with $50 \mathrm{mM}$ Tris/ $\mathrm{HCl}$ buffer (pH 8.0) containing $500 \mathrm{mM} \mathrm{NaCl}$ and $10 \mathrm{mM}$ imidazole. PepP was eluted in a step in which the imidazole concentration was increased to $500 \mathrm{mM}$ (after $\sim 40 \mathrm{~min}$ ) in the same buffer. Subsequently, the purified PepP was automatically desalted in $50 \mathrm{mM}$ Tris/ $\mathrm{HCl}$ buffer ( $\mathrm{pH} 7.0)$. Finally, an enzyme activity yield of $82 \%$ and a purification factor of 22.9 (specific activity: 3682 nkat $_{\text {LPP }} \mathrm{mg}_{\text {protein }}^{-1}$ ) were determined for PepP.

SDS-PAGE analysis of the samples during cultivation showed an overexpression band at approximately $40 \mathrm{kDa}$ for PepP (data not shown). Thus, PepP could be determined in both the soluble and insoluble fractions (inclusion bodies; data not shown). SDS-PAGE analysis after purification showed that PepP bound strongly to the affinity chromatography material (see Figure 4; SDSPAGE, lane 2), as no significant amount of the His-tagged recombinant PepP was eluted in the flowthrough fractions.

Performing native-PAGE together with Coomassie and specific activity staining of PepP after purification revealed bands of approximately $40 \mathrm{kDa}$ (see arrows in

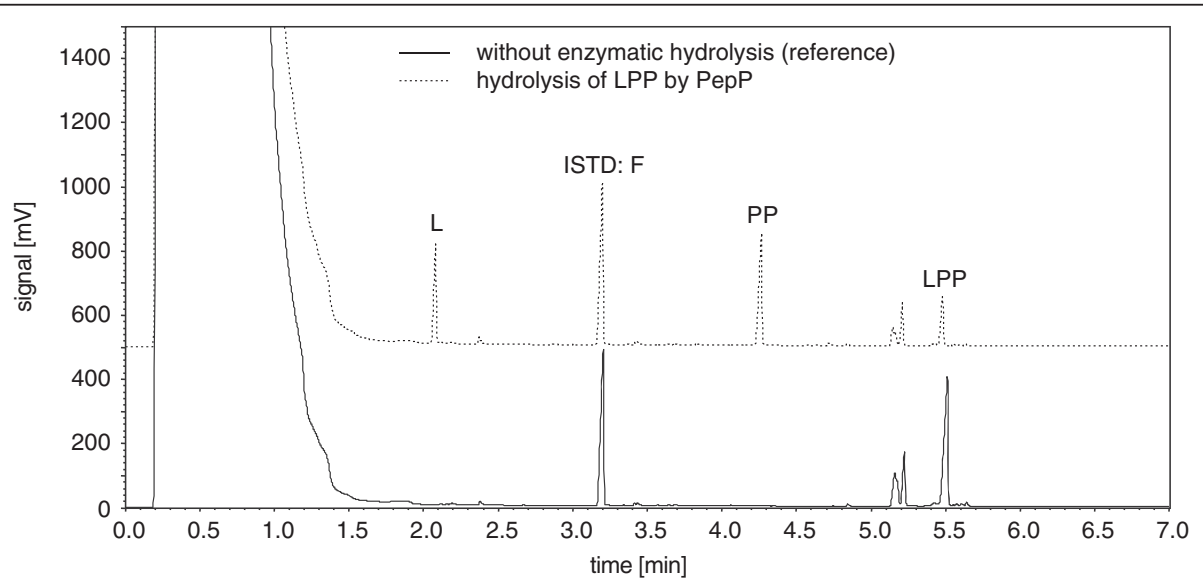

Figure 1 GC-FID chromatograms before and after hydrolysis of LPP by PepP. (L: L-leucine; ISTD: internal standard, F: L-phenylalanine; PP: L-prolyl-L-proline; LPP: L-leucine-L-prolyl-L-proline). 


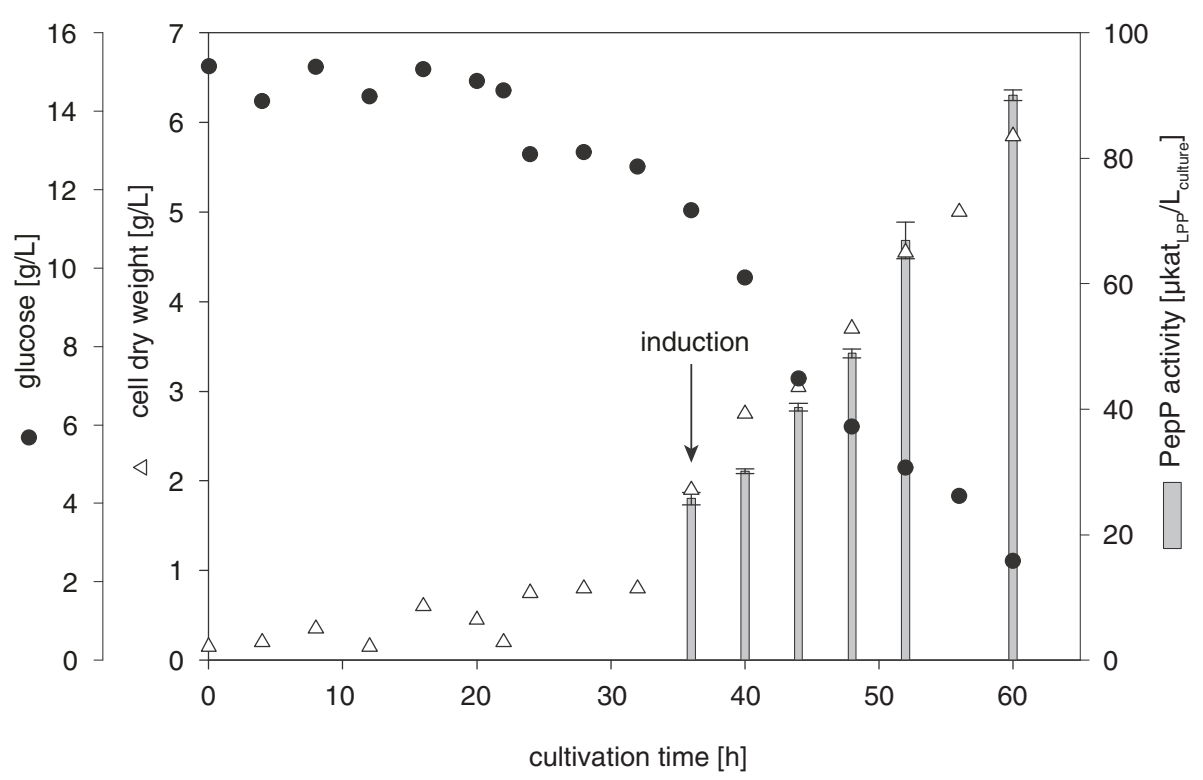

Figure 2 Production of PepP from Lactococcus lactis ssp. lactis DSM 20481 in E. coli BL21 in a bioreactor. (working volume: $800 \mathrm{~mL}$; 2xYT medium; $16^{\circ} \mathrm{C}$; induction with $0.5 \mathrm{mM} \mathrm{IPTG)}$.

Figure 4). These results indicated that the purified PepP was a monomer with a molecular mass of approximately $40 \mathrm{kDa}$ (calculated based on the amino acid sequence including a His-tag: $40.6 \mathrm{kDa}$ ).

Staining to detect the specific activity of PepP was also employed to evaluate the separation of the native $E$. coli PepP [see above; homotetramer, $200 \mathrm{kDa}$; Yoshimoto et al. 1988a] from the recombinant produced PepP during the purification process (see Materials and methods). The recombinant purified PepP contained no activity stained band at $200 \mathrm{kDa}$. Thus, it can be assumed that no native PepP from the E. coli host or other LPP hydrolyzing enzymes were present in the purified, recombinant enzyme preparation and that all of the determined enzyme characteristics were associated with the new, recombinant PepP produced from Lactococcus lactis ssp. lactis DSM 20481.

\section{Characterization of purified PepP \\ Temperature and $\mathrm{pH}$ optimum}

The $\mathrm{pH}$ optimum was assayed by measuring enzyme activities at different $\mathrm{pH}$ levels (Figure 5A). PepP showed the highest activity between $\mathrm{pH} 7$ and 7.5 when using $50 \mathrm{mM}$ Bis-Tris/ $\mathrm{HCl}$ buffer. A strong negative buffer effect was detected when using $50 \mathrm{mM} \mathrm{Na} 2 \mathrm{HPO}_{4} / \mathrm{KH}_{2} \mathrm{PO}_{4}$ (pH 5.0 to 7.0 ).

To investigate the optimal reaction temperatures for PepP, the hydrolysis of LPP was assayed at different temperatures (Figure 5B). PepP showed the highest activity between $50^{\circ} \mathrm{C}$ and $60^{\circ} \mathrm{C}$ and was inactivated at $70^{\circ} \mathrm{C}$.

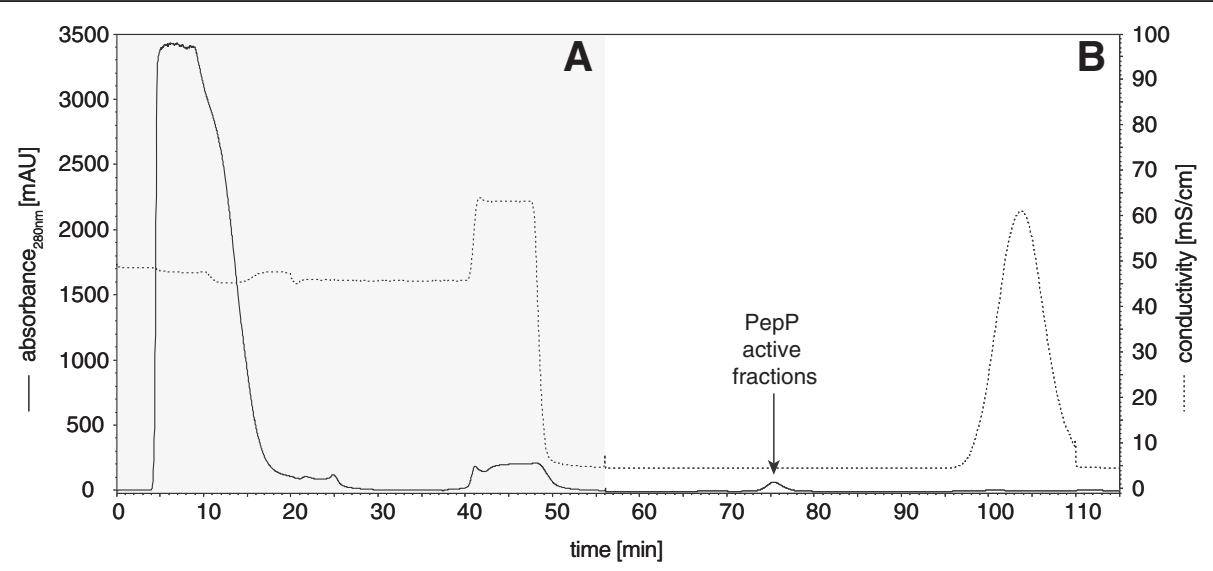

Figure 3 Automated purification of recombinant PepP using (A) $\mathrm{Ni}^{2+}$-affinity chromatography and (B) two HiPrep ${ }^{\mathrm{TM}} 26 / 10$ columns (desalting). 


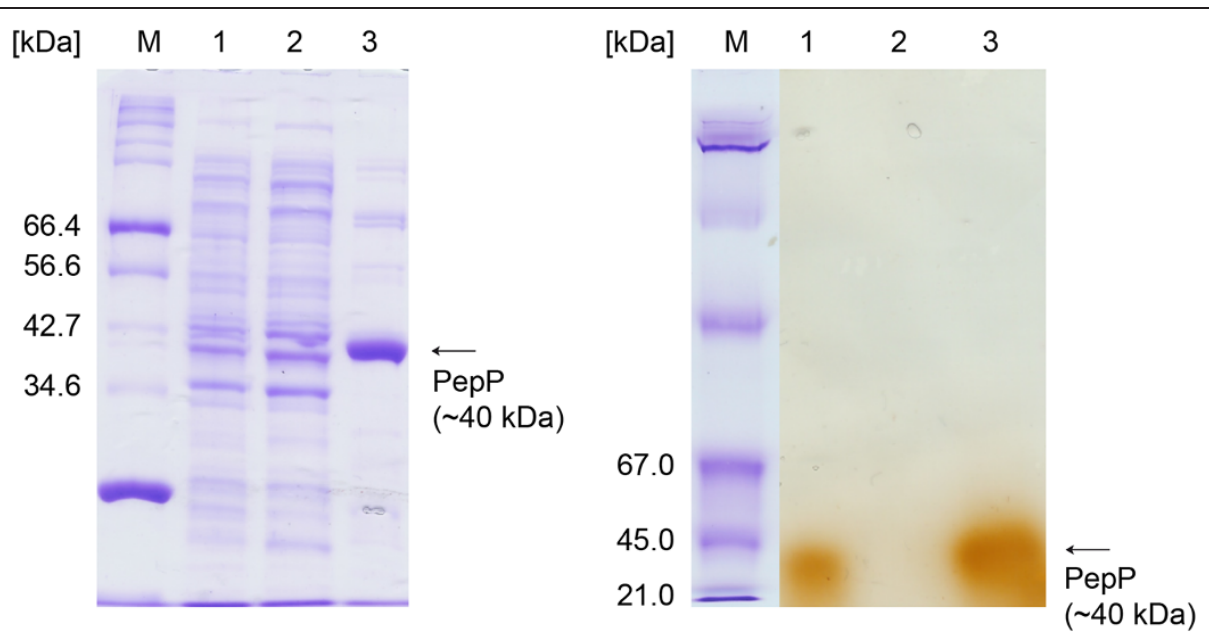

Figure 4 SDS-PAGE (left; Coomassie stained) and native-PAGE (right; lanes 1 - 3 active stained) analyses of recombinant PepP produced in E. coli BL21 (DE3) during purification. (M: Molecular weight marker; lane 1: crude cell extract before purification; lane 2: pooled flow-through fractions: lane 3: pooled purified fractions after desalting).

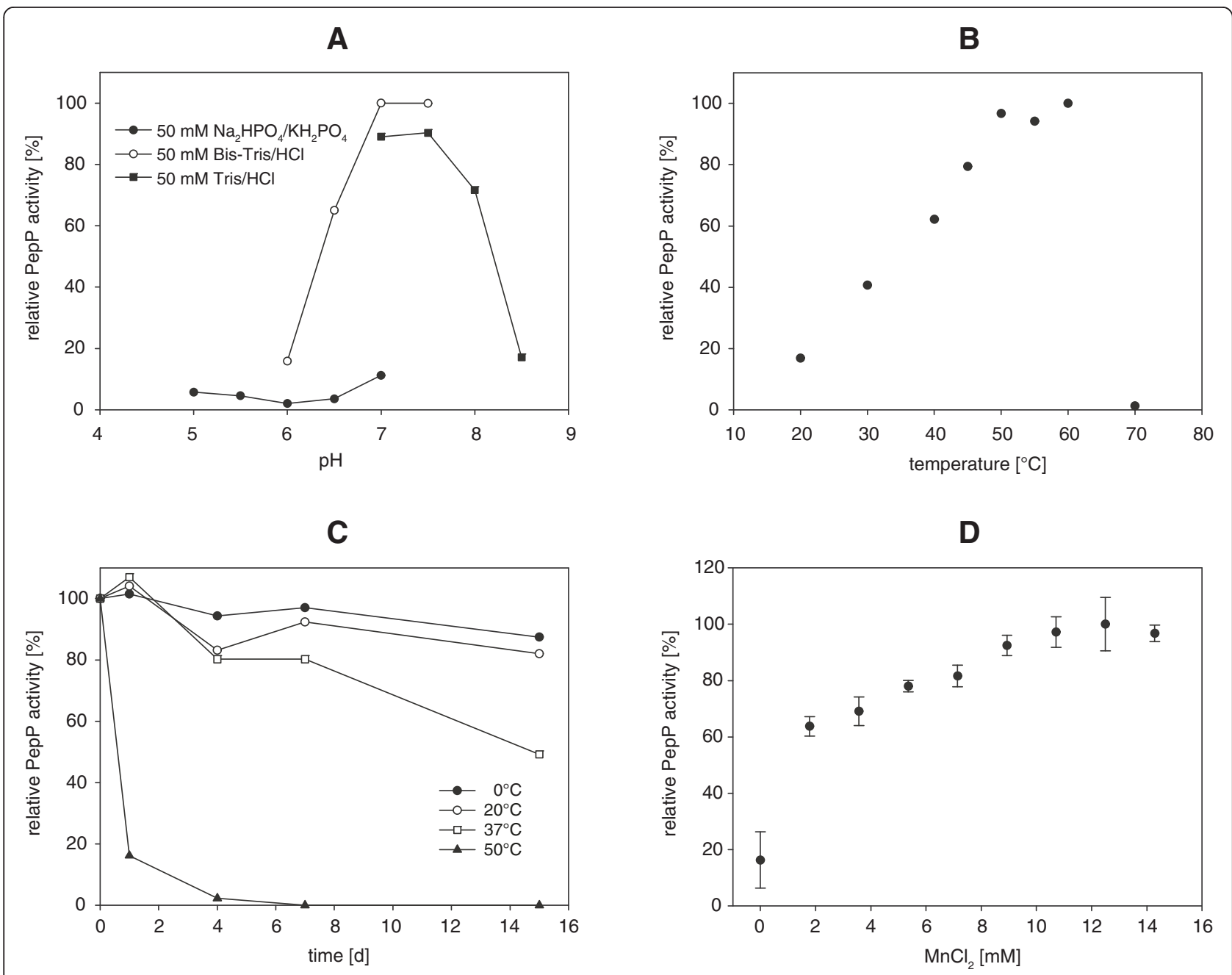

Figure 5 Characterization of recombinant purified PepP from Lactococcus lactis ssp. lactis DSM 20481. (A: pH profile; B: temperature profile; C: temperature stability; $\mathbf{D}$ : influence of $\mathrm{MnCl}_{2} ; \mathrm{n}=3$, standard deviations $<5 \%$ are not shown). 
The temperature stability of PepP was determined by preincubating purified PepP in $50 \mathrm{mM}$ Tris/ $\mathrm{HCl}$ buffer, $\mathrm{pH} 7.0$, at different temperatures $\left(0,20,37\right.$ and $\left.50^{\circ} \mathrm{C}\right)$. The highest temperature stability of PepP (Figure $5 \mathrm{C}$ ) was found at $0^{\circ} \mathrm{C}$ and $20^{\circ} \mathrm{C}(87 \%$ residual activity and $82 \%$ residual activity after 15 days of incubation, respectively). Approximately 49\% residual PepP activity was detected at $37^{\circ} \mathrm{C}$ after 15 days. At the temperature optimum for PepP $\left(50^{\circ} \mathrm{C}\right)$, the residual activity after one day was $16 \%$, and no activity could be observed after 7 days of incubation at this temperature.

\section{Influence of freezing and thawing}

Purified PepP was stored at $-80^{\circ} \mathrm{C}$ over a period of 15 days. During this time, aliquoted samples were checked for residual activities and no significant inactivation of PepP was observed (97\% residual activity; data not shown). Additionally, the influence of 6 alternating cycles of freezing and thawing was observed. The residual activity of PepP was $87 \%$ after these cycles (data not shown).

\section{Effect of $\mathrm{Mn}^{2+}$-ions on PepP enzyme activity}

To investigate the optimal $\mathrm{Mn}^{2+}$ concentration for PepP activity, $\mathrm{MnCl}_{2}$ was used in different concentrations, with the final concentrations ranging from $0 \mathrm{mM}$ to $14.28 \mathrm{mM}$ (Figure 5D). The PepP activity obtained without added $\mathrm{MnCl}_{2}$ was 3.9-fold lower compared to $1.79 \mathrm{mM} \mathrm{MnCl} 2 . \mathrm{MnCl}_{2}$ exerted a favorable effect on PepP activity up to a final $\mathrm{MnCl}_{2}$ concentration of
$8.92 \mathrm{mM}$. Between $8.92 \mathrm{mM}$ and $14.28 \mathrm{mM}$, no additional significant increase of PepP activity was detected (approximately 6-fold increases compared to the reference for all of these concentrations).

\section{Enzyme kinetics}

The kinetics were determined for PepP using LPP, IPP and VPP as peptide substrates. The $K_{m}$ values and $V_{\max }$ values were calculated by linearization following Hanes (for an example, see Figure 6). The $K_{m}$ and $V_{\max }$ values calculated for PepP when using LPP as substrate were $4.7 \mathrm{mM}$ and 101 nkat $\mathrm{mL}^{-1}$, respectively. The kinetics of PepP with IPP and VPP as substrates were found to present values of $2.5 \mathrm{mM}$ and $13.6 \mathrm{mM}$ for $K_{m}$ and 74 nkat $\mathrm{mL}^{-1}$ and $145 \mathrm{nkat} \mathrm{mL}^{-1}$ for $V_{\max }$, respectively.

\section{Effect of metal ions on enzyme activity}

PepP was observed to be inhibited by several different divalent cations (see Table 1), despite fact that the standard assay was performed in the presence of an optimal $\mathrm{MnCl}_{2}$ concentration. Almost complete inhibition of enzyme activity was caused by $10 \mathrm{mM} \mathrm{CuCl}, 1 \mathrm{mM} \mathrm{SnCl}_{2}$ or $10 \mathrm{mM} \mathrm{ZnCl}_{2}$. Additionally, marked inhibition was observed in the presence of $10 \mathrm{mM} \mathrm{CoCl}_{2}$ (63\% residual activity), $0.1 \mathrm{mM} \mathrm{CuCl} 2$ (73\% residual activity) and $0.01 \mathrm{mM} \mathrm{ZnCl}_{2}$ (59\% residual activity). A concentration of $1 \mathrm{mM} \mathrm{CoCl}_{2}$ reduced the PepP activity to $86 \%$. The divalent cation $\mathrm{Mg}^{2+}$ (from $\mathrm{MgCl}_{2}$ ) was associated with only weak inhibition up to a concentration of $10 \mathrm{mM}$ (88\% residual activity).

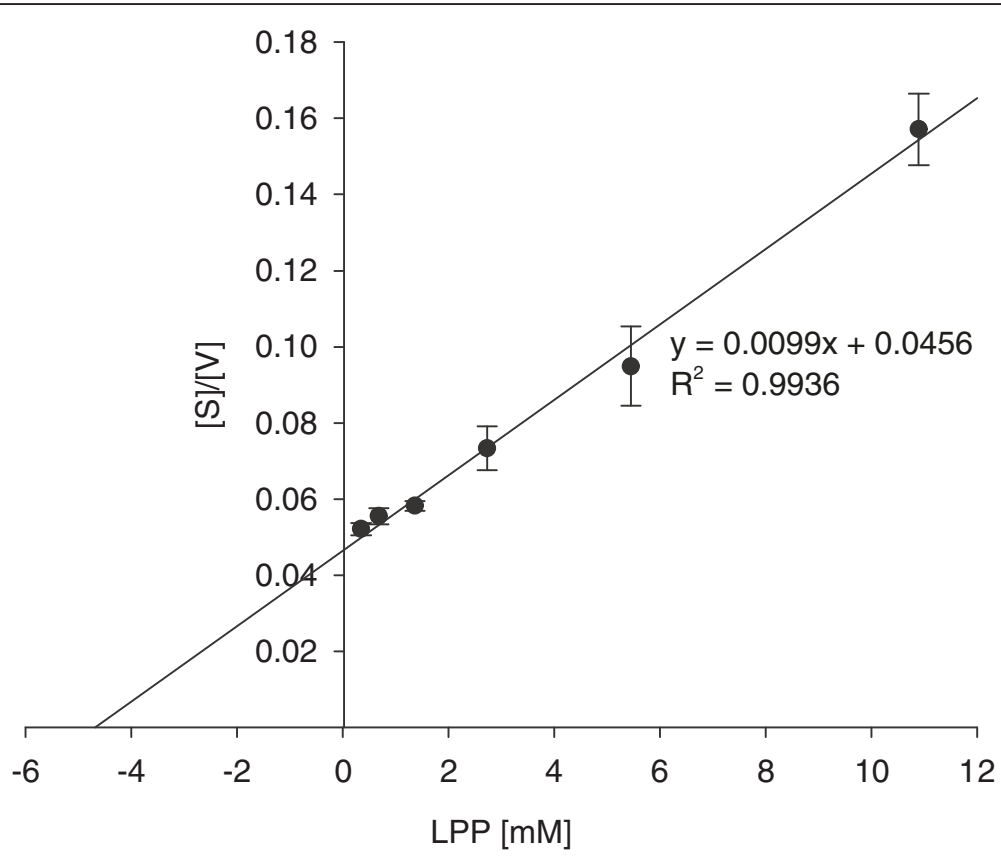

Figure 6 Calculation of $K_{m}$ and $V_{\text {max }}$ for PepP via a Hanes plot using LPP as a substrate. 
Table 1 Effect of several solvents, cations, inhibitors, reducing agents and metal chelators on the activity of PepP of Lactococcus lactis ssp. lactis DSM 20481

\begin{tabular}{|c|c|c|c|c|c|c|}
\hline & Substance & Concentration & Activity $^{1}[\%]$ & Substance & Concentration & Activity $^{1}[\%]$ \\
\hline \multirow[t]{2}{*}{ Solvents [\% (v/v)] } & Acetone & 10 & 79 & DMSO & 10 & 51 \\
\hline & $\mathrm{EtOH}$ & & 52 & & & \\
\hline \multirow[t]{9}{*}{ Cations $^{2}[\mathrm{mM}]$} & $\mathrm{Co}^{2+}$ & 0.1 & 97 & $\mathrm{Sn}^{2+}$ & 0.1 & 81 \\
\hline & & 1 & 86 & & 1 & 4 \\
\hline & & 10 & 63 & & 10 & 3 \\
\hline & $\mathrm{Cu}^{2+}$ & 0.1 & 73 & $\mathrm{Zn}^{2+}$ & 0.001 & 100 \\
\hline & & 1 & 3 & & 0.01 & 59 \\
\hline & & 10 & 3 & & 0.1 & 4 \\
\hline & $\mathrm{Mg}^{2+}$ & 0.1 & 97 & & & \\
\hline & & 1 & 89 & & & \\
\hline & & 10 & 88 & & & \\
\hline \multirow[t]{13}{*}{ Reagents [mM] } & $\beta$-mercaptoethanol ${ }^{2}$ & 0.1 & 100 & Pepstatin $\mathrm{A}^{3}$ & 0.001 & 113 \\
\hline & & 1 & 97 & & 0.01 & 111 \\
\hline & & 10 & 106 & & 0.1 & 111 \\
\hline & $\mathrm{D} \pi^{2}$ & 0.1 & 99 & 1,10- phenanthroline ${ }^{4}$ & 0.1 & 103 \\
\hline & & 1 & 84 & & 1 & 96 \\
\hline & & 10 & 51 & & 10 & 53 \\
\hline & EDTA $^{2}$ & 0.1 & 105 & & 30 & 13 \\
\hline & & 1 & 102 & PMSF $^{5}$ & 0.1 & 120 \\
\hline & & 10 & 100 & & 1 & 114 \\
\hline & & 30 & 1 & & 10 & 10 \\
\hline & Imidazole $^{2}$ & 0.1 & 112 & & & \\
\hline & & 1 & 107 & & & \\
\hline & & 10 & 109 & & & \\
\hline
\end{tabular}

${ }^{1}$ For each enzyme activity test an individual $100 \%$ value was determined in relation to the corresponding solvent.

${ }^{2}$ dissolved in $\mathrm{H}_{2} \mathrm{O}_{\text {dd }} i^{3}$ dissolved in DMSO; ${ }^{4}$ dissolved in Acetone; ${ }^{5}$ dissolved in EtOH.

$\mathrm{n}=3$; all standard deviations $<5 \%$.

Effect of solvents, inhibitors, reducing agents and metal chelators on enzyme activity

The influences of several solvents and other agents on the PepP activity are also shown in Table 1. The PepP enzyme activity was reduced by the half when using $10 \%$ $(\mathrm{v} / \mathrm{v})$ ethanol or DMSO. Acetone $[10 \%(\mathrm{v} / \mathrm{v})]$ reduced the PepP activity to $79 \%$. Almost no inhibition of PepP activity was observed under up to $1 \mathrm{mM}$ PMSF (phenylmethylsulfonyl fluoride), which is a specific inhibitor of serine peptidases. Surprisingly, $10 \mathrm{mM}$ PMSF reduced the PepP activity to $10 \%$ residual activity. In experiments using Pepstatin A, a specific carboxy peptidase inhibitor, no inhibition of PepP activity was detected. Preincubation of the enzyme with the reducing agent $\beta$-mercaptoethanol had no effect on the activity of PepP. However, the PepP activity decreased approximately 50\% using $10 \mathrm{mM}$ DTT (dithiothreitol). Imidazole did not lead to any inhibition of PepP activity at a concentration of up to $10 \mathrm{mM}$. Metal complexing reagents such as
EDTA and 1,10-phenanthroline produced no inactivation up to $10 \mathrm{mM}$. However, at higher concentrations (30 $\mathrm{mM}$ ), total inhibition was observed under EDTA treatment, and strong inhibition (13\% residual activity) was detected under 1,10-phenanthrolinetreatment. The reason for this pattern was the high content of $\mathrm{MnCl}_{2}$ $(10.71 \mathrm{mM})$ in the activity buffer. These results indicated that PepP is a metallopeptidase.

\section{Discussion}

The classical assay methods for PepP activity determination present some problems (Yoshimoto et al. 1988b; McDonnell et al. 1997; Lasch et al. 1988; Fleminger et al. 1982; Holtzman et al. 1987; Hawthorne et al. 1997; Stöckel-Maschek et al. 2003). A precise determination of PepP activity using ninhydrin is nearly impossible because crude extracts contain large amounts of ninhydrinpositive substances (Yoshimoto et al. 1988b). It is also difficult to measure an initial reaction velocity via fluorometric 
methods (Doi et al. 1981). The method employing GlyPro- $p$ NA coupled with proline iminopeptidase (Yoshimoto et al. 1988b) can be used for routine assays, but not for screening the PepP enzyme activity in crude extracts from lactic acid bacteria without further pre-treatment because of the existence of parallel PepX activity (X-prolyl dipeptidyl aminopeptidase; EC 3.4.14.11), which is common in lactic acid bacteria. Our novel assay method using gas chromatography for detection of the release of Lleucine during hydrolysis of the substrate (LPP) could be used for routine analysis as well as for screening experiments. Even when free amino acids are present in the crude extract, or other aminopeptidases are present, such as PepX, which did not hydrolyze Xaa-Pro-Pro peptide sequences, our GC assay is applicable and specific for PepP activity.

The gene (EMBL: CCC78909) of Lactobacillus plantarum WCFS1 encodes Xaa-Pro aminopeptidase (PepP). The gene encoding PepP in Lactobacillus plantarum NC8 showed 99\% nucleotide and amino acid sequence identities (1 different amino acid) compared to Lactobacillus plantarum WCFS1. However, no PepP activity of Lb. plantarum NC8 was detected, even though overexpression was visible in SDS-PAGE gels.

In the literature, several lactococcus strains showing PepP activity have been reported (Mars and Monnet 1995; McDonnell et al. 1997; Matos et al. 1998). Therefore, we cloned the pepP gene of Lactococcus lactis ssp. lactis DSM 20481. To best of our knowledge, we are the first to express PepP from a lactococcal strain in E. coli. During our experiments, we found that expression at common temperatures $\left(30^{\circ} \mathrm{C}\right.$ and $\left.37^{\circ} \mathrm{C}\right)$ resulted in insoluble recombinant PepP (inclusion bodies). When the cultivation temperature was decreased to $20^{\circ} \mathrm{C}$ (shaking flasks) or $16^{\circ}$ $\mathrm{C}$ (bioreactor), the insolubility of PepP was partially overcome. Protein expression in E. coli at $15^{\circ} \mathrm{C}$ to $25^{\circ} \mathrm{C}$ is widely used to increase the solubility of recombinant proteins (Song et al. 2012). Here, it was demonstrated for all of the investigated recombinant proteins $(\beta$-mannanase, cellulase and lipase), which formed inclusion bodies when overexpressed at $15^{\circ} \mathrm{C}$ to $37^{\circ} \mathrm{C}$, that they were expressed as soluble forms in E. coli when the temperature was lowered below $10^{\circ} \mathrm{C}$. The reason for soluble protein production below $10^{\circ} \mathrm{C}$ was not clear. It has been discussed that the reason for this phenomenon may be the reduced growth rates at $6^{\circ} \mathrm{C}$ to $10^{\circ} \mathrm{C}$ (Song et al. 2012). Nevertheless, $E$. coli can still grow at 7.5 to $7.8^{\circ} \mathrm{C}$, although its growth rate is drastically decreased (Shaw et al. 1971). We observed only slow growth of E. coli during the first $35 \mathrm{~h}$ of cultivation at $16^{\circ} \mathrm{C}$, until exponential growth began. The maximal achieved PepP activity was $90 \mu \mathrm{kat}_{\mathrm{LPP}} \mathrm{L}_{\text {culture }}^{-1}$ After automated purification, a 700-fold higher enzyme activity of $73.8 \mu \mathrm{kat}_{\mathrm{LPP}} \mathrm{L}_{\text {culture }}^{-1}$ was achieved compared to the activity of $0.105 \mu \mathrm{kat}_{\text {bradykinin }} \mathrm{L}_{\text {culture }}^{-1}$ for the native
PepP produced and purified from Lactococcus lactis ssp. lactis NCDO 763 (Mars and Monnet 1995). Furthermore, the specific activity of the recombinant PepP that was produced and purified (3682 nkat $\mathrm{LPP}_{\mathrm{LP}} \mathrm{mg}^{-1}$ ) was approximately $20 \%$ higher than that of the native produced and purified PepP (3073 nkat bradykinin $\mathrm{mg}^{-1}$ ). Moreover, compared to the native PepP produced and purified from Lactococcus lactis ssp. cremoris AM2 (22.8 nkat LPP $_{\text {mg }}{ }^{-1}$; McDonnell et al. 1997), the specific PepP activity of the recombinant produced and purified PepP was 165 -fold higher.

The observed molecular weight of PepP of $\sim 40 \mathrm{kDa}$ (monomer) agreed well with the values reported for PepP from Lactococcus lactis ssp. cremoris AM2 [40 kDa (McDonnell et al. 1997)] and from Lactococcus lactis ssp. lactis NCDO 763 [43 kDa (Mars and Monnet 1995)]. This weight is much lower than has been reported for E. coli PepP [homotetramer, $200 \mathrm{kDa}$ (Yoshimoto et al. 1988b)] or mammalian PepP [homodimer, $143 \mathrm{kDa}$ (Harbeck and Mentlein 1991)]. The enzyme examined in the present study appeared to be a metalloenzyme stimulated by $\mathrm{Mn}^{2+}$, similar to the PepPs from Lactococcus lactis ssp. cremoris AM2 (McDonnell et al. 1997) and Lactococcus lactis ssp. lactis NCDO 763 (Mars and Monnet 1995). Like the Lactococcus lactis enzyme (Mars and Monnet 1995), the present enzyme was inhibited by DTT, whereas Lactococcus lactis ssp. cremoris AM2 PepP is (McDonnell et al. 1997). In our study, we used the same substrate (LPP) as McDonnell et al. (1997), but a different detection method because quantification using the ninhydrin detection method was inappropriate in our case (data not shown). We determined a pH optimum for PepP between 7 and 7.5, while PepP from Lactococcus lactis ssp. lactis NCDO 763 (Mars and Monnet 1995) showed a pH optimum of 8 , and the Lactococcus lactis ssp. cremoris AM2 PepP (McDonnell et al. 1997) displayed an optimum activity at $\mathrm{pH}$ 8.5. The determined $K_{m}$ value for PepP when using LPP as substrate was $4.7 \mathrm{mM}$ and, thus, was higher than that of Lactococcus lactis ssp. cremoris AM2 (0.9 $\mathrm{mM}_{\mathrm{LPP}}$; McDonnell et al. 1997).

Aminopeptidase P may be involved in supplying proline in lactococcoal strains (Mars and Monnet 1995). Caseins, especially $\beta$-casein, can be hydrolyzed by proteinases and by aminopeptidases located on the cell envelope, releasing several sequences with Xaa-Pro-Pro N-termini, which cannot cleaved by lactococcal PepX (Lloyd and Pritchard 1991) but can be cleaved by PepP. Much research has focused on the application of proline-specific exopeptidases in hydrolysate debittering strategies due to the inability of most general aminopeptidases to hydrolyze the imino bond (FitzGerald and O'Cuinn 2006). Highly significant reductions in casein hydrolysate bitterness can be achieved using X-prolyl-dipeptidyl aminopeptidase (PepX), which releases amino acyl proline residues from 
the N-terminus, in conjunction with the activity of a general aminopeptidase (PepN; EC 3.4.11.2) (FitzGerald and O'Cuinn 2006). PepX together with PepP can mediate the hydrolysis of proline-rich substrates, i.e., those containing single and consecutive prolines (Bouchier et al. 1999; O'Cuinn et al. 1999).

Recombinant production of PepP provides the opportunity for further investigations regarding the debittering process of protein hydrolysates in large-scale applications. Thus, industrial application of PepP might be desirable in the future.

\section{Additional files}

Additional file 1: Scheme of the automated purification. This file contains the general flow scheme of the automated purification for proteins.

Additional file 2: Scheme of active staining. This file contains the visualization scheme for activity staining of PepP.

Additional file 3: Sequences of pepP/PepP. This file contains the nucleotide sequence of the pepP gene and the translated amino acid sequence from Lactococcus lactis ssp. lactis DSM 20481.

Additional file 4: Sequences of pepP/PepP. This file contains the nucleotide sequence of the pepP gene and the translated amino acid sequence from Lactobacillus plantarum NC8.

\section{Competing interests}

The authors declare that they have no competing interests.

\section{Acknowledgments}

We thank Dr. Lars Axelsson of the MATFORSK Norwegian Food Research Institute for providing the strain Lactobacillus plantarum NC8. The authors also thank Wissenschaftliche Gerätebau Dr.-Ing. Herbert Knauer for providing the Bioline chromatography system. We are also grateful to Dr. Markus Fuchs, Katrin Schubert and Dr. Melanie Näther of Wissenschaftliche Gerätebau Dr.-Ing. Herbert Knauer for technical support, and we thank Dipl. Ing. (FH) Wolfgang Claaßen of the University of Hohenheim, Institute of Food Science and Biotechnology, Department of Biotechnology for his technical support of this work. Furthermore, we express our gratitude to the German Federal Ministry of Economics and Technology (AIF/FEl Project No. $16541 \mathrm{~N})$ for partial financial support of this research.

Received: 13 July 2012 Accepted: 20 July 2012

Published: 1 August 2012

\section{References}

Altschul SF, Gish W, Miller W, Myers EW, Lipman DJ (1990) Basic local alignment search tool. J Mol Biol 215:403-410

Bouchier PJ, Fitzgerald RJ, O'Cuinn G (1999) Hydrolysis of a(s1)- and $\beta$-casein-derived peptides with a broad specificity aminopeptidase and proline specific aminopeptidases from Lactococcus lactis subsp. cremoris AM2. FEBS Lett 445:321-324

Bouchier PJ, O'Cuinn G, Harrington D, FitzGerald RJ (2001) Debittering and hydrolysis of a tryptic hydrolysate of $\beta$-casein with purified general and proline specific aminopeptidases from Lactococcus lactis ssp. cremoris AM2. J Food Sci 66:816-820

Bradford MM (1976) A rapid and sensitive method for the quantitation of microgram quantities of protein utilizing the principle of protein dye binding. Anal Biochem $72: 248-254$

Chen KCS, Buchanan TM (1980) Hydrolases from Neisseria gonorrhoeae. The study of gonocosin, an aminopeptidase-P, a proline iminopeptidase, and an asparaginase. J Biol Chem 255:1704-1710

Cunningham DF, O'Connor B (1997) Proline specific peptidases. Biochimica et Biophysica Acta - Protein Structure and Molecular Enzymology 1343:160-186

Doi E, Shibata D, Matoba T (1981) Modified colorimetric ninhydrin methods for peptidase assay. Anal Biochem 118:173-184
FitzGerald RJ, O'Cuinn G (2006) Enzymatic debittering of food protein hydrolysates. Biotechnol Adv 24:234-237

Fleminger G, Carmel A, Goldenberg D, Yaron A (1982) Fluorogenic substrates for bacterial aminopeptidase $P$ and its analogs detected in human serum and calf lung. Eur J Biochem 125:609-615

Gish W, States DJ (1993) Identification of protein coding regions by database similarity search. Nat Genet 3:266-272

Harbeck H, Mentlein R (1991) Aminopeptidase P from rat brain. Purification and action on bioactive peptides. Eur J Biochem 198:451-458

Hawthorne SJ, Harriott P, Lim J, Turner AJ, Walker B, Williams CH (1997) Evaluation of some fluorogenic substrates for continuous assay of aminopeptidase P. Anal Biochem 253:13-17

Holtzman EJ, Pillay G, Rosenthal T, Yaron A (1987) Aminopeptidase P activity in rat organs and human serum. Anal Biochem 162:476-484

Hooper NM, Hryszko J, Turner AJ (1990) Purification and characterization of pig kidney aminopeptidase P: a glycosyl-phosphatidylinositol-anchored Actoenzyme. Biochem J 267:509-515

Husek P (1991) Amino acid derivatization and analysis in five minutes. FEBS Lett 280:354-356

Laemmli UK (1970) Cleavage of structural proteins during the assembly of the head of bacteriophage T4. Nature 227:680-685

Lasch J, Koelsch R, Steinmetzer T, Neumann U, Demuth H (1988) Enzymic properties of intestinal aminopeptidase P: A new continuous assay. FEBS Lett 227:171-174

Lee HS, Kim YJ, Bae SS, Jeon JH, Lim JK, Jeong BC, Kang SG, Lee J (2006) Cloning, expression, and characterization of aminopeptidase $P$ from the hyperthermophilic archaeon Thermococcus sp. strain NA1. Appl Environ Microbiol 72:1886-1890

Lewis WHP, Harris H (1967) Human red cell peptidases. Nature 215:351-355

Lloyd RJ, Pritchard GG (1991) Characterization of X-prolyl dipeptidyl aminopeptidase from Lactococcus lactis subsp. lactis. J Gen Microbiol 137:49-55

Mars I, Monnet V (1995) An aminopeptidase P from Lactococcus lactis with original specificity. Biochimica et Biophysica Acta - General Subjects 1243:209-215

Matos J, Nardi M, Kumura H, Monnet V (1998) Genetic characterization of pepP, which encodes an aminopeptidase P whose deficiency does not affect Lactococcus lactis growth in milk, unlike deficiency of the X-prolyl dipeptidyl aminopeptidase. Appl Environ Microbiol 64:4591-4595

McDonnell M, Fitzgerald R, Ni Fhaoláin I, Jennings PV, O'Cuinn G (1997) Purification and characterization of aminopeptidase P from Lactococcus lactis subsp. cremoris. J Dairy Res 64:399-407

O'Cuinn G, FitzGerald R, Bouchier P, McDonnell M (1999) Generation of non-bitter casein hydrolysates by using combinations of a proteinase and aminopeptidases. Biochem Soc Trans 27:730-734

Oliveira C, Guimarães PMR, Domingues L (2011) Recombinant microbial systems for improved $\beta$-galactosidase production and biotechnological applications. Biotechnol Adv 29:600-609

Sambrook J, Russell DW (2001) Molecular cloning: a laboratory manual. Cold Spring Harbor Laboratory Press, Cold Spring Harbor, N.Y

Schechter I, Berger A (1967) On the size of the active site in proteases. I. Papain. Biochem Biophys Res Commun 27:157-162

Shaw MK, Marr AG, Ingraham JL (1971) Determination of the minimal temperature for growth of Escherichia coli. J Bacteriol 105:683-684

Song JM, An YJ, Kang MH, Lee Y, Cha S (2012) Cultivation at $6-10^{\circ} \mathrm{C}$ is an effective strategy to overcome the insolubility of recombinant proteins in Escherichia coli. Protein Expr Purif 82:297-301

Stöckel-Maschek A, Stiebitz B, Koelsch R, Neubert K (2003) A continuous fluorimetric assay for aminopeptidase $\mathrm{P}$ detailed analysis of product inhibition. Anal Biochem 322:60-67

Yaron A, Mlynar D (1968) Aminopeptidase-P. Biochem Biophys Res Commun 32:658-663

Yaron A, Naider F (1993) Proline-dependent structural and biological properties of peptides and proteins. Crit Rev Biochem Mol Biol 28:31-81

Yoshimoto T, Murayama N, Honda T, Tone H, Tsuru D (1988a) Cloning and expression of aminopeptidase P gene from Escherichia coli HB101 and characterization of expressed enzyme. J Biochem 104:93-97

Yoshimoto T, Murayama N, Tsuru D (1988b) A novel assay method for aminopeptidase $P$ and partial purification of two types of the enzyme in Escherichia coli. Agric Biol Chem 52:1957-1963

doi:10.1186/2191-0855-2-39

Cite this article as: Stressler et al:: Production, active staining and gas chromatography assay analysis of recombinant aminopeptidase $\mathrm{P}$ from Lactococcus lactis ssp. lactis DSM 20481. AMB Express 2012 2:39. 